\section{Canadian Virtual Health Library / Bibliothèque virtuelle canadienne de la santé (CVHL / BVCS)}

The Canadian Virtual Health Library / Bibliothèque virtuelle canadienne de la santé (CVHL / BVCS) is pleased to share its progress to date.

\section{Stakeholder engagement and network formation}

For the past four years, the CVHL / BVCS has been led by a Task Force of dedicated volunteers that have worked relentlessly towards the pursuit of equal access to health information. The work of the Task Force has now transitioned to a Board of Directors, who will be the governing body of the CVHL / BVCS. The Board of Directors includes two Canadian Health Libraries Association / Association des bibliothèques de la santé du Canada (CHLA / ABSC) representatives.

Over the last 6 months, CHLA / ABSC chapters have had the opportunity to host an information session on the CVHL / BVCS. Feedback has been positive; attendees have asked important questions, provided valuable input, and have found the presentations extremely informative. The following chapters have hosted an information session:

- Health Libraries Association of British Columbia;

- Manitoba Association of Health Information Professionals;

- Maritimes Health Libraries Association;

- Northern Alberta Health Libraries Association;

- Northern Lights Health Libraries Association;

- Saskatchewan Health Libraries Association;

- Southern Alberta Health Libraries Association;

- Southwestern Ontario Health Libraries Information Network; and

- Wellington-Waterloo-Dufferin Health Library Network.

The Quebec chapter of CHLA / ABSC, Association pour l'avancement des sciences et des techniques de la documentation (ASTED) Section santé, organized a presentation on the CVHL / BVCS at the Congrès des milieu documentaires du Québec in November 2010. Co-investigator Jim Henderson presented "La Bibliothèque virtuelle canadienne de la santé : un accès aux connaissances pour les professionnels de la santé du pays". As well, Patrick Ellis, Jim Henderson, and Jessie McGowan presented "CVHL: A network for improved access to health information" at the Ontario Library Association-Super Conference in February 2011.

\section{Content strategy}

The CVHL / BVCS is pleased to announce the following participants as confirmed network subscribers:

- Atlantic Health Knowledge Network (AHKN);

- The Consortium of Ontario Academic Health Libraries (COAHL);

- Health Sciences Information Consortium of Toronto (HSICT);

- New Brunswick Hospital Consortium (NBHC);

- Newfoundland and Labrador Health Knowledge Information Network (NLHKIN);

- University of Manitoba; and

- Western Ontario Health Knowledge Network (WOHKN).

- Consortium des ressources electroniques du RUIS de l'UdeM (RUIS)

Network subscribers consist of provincial, national, or territorial consortia or professional associations that license health-information resources on behalf of their members. Network subscribers partner with the CVHL / BVCS to participate in the collective purchasing of content and services.

\section{IT strategy}

As part of the Portal Strategy, the Day 1 website will be launched in the spring of 2011. The CVHL / BVCS website has also launched a new look with the introduction of an updated logo and other graphics. Additional information and future announcements on the progress of the new website will be available on http://chla-absc.ca/nnlh/cvhl/.

\section{Become involved}

Do you believe in the vision and mission of the CVHL / BVCS? Consider volunteering with the CVHL / BVCS to share your expertise. If interested, please contact Jennifer Bayne.

Patrick Ellis

Principal Investigator

Canadian Virtual Health Library / Bibliothèque virtuelle canadienne de la santé

E-mail:Patrick.Ellis@dal.ca

Jennifer Bayne

Project Lead

Canadian Virtual Health Library / Bibliothèque virtuelle canadienne de la santé

E-mail: jennifer.bayne@knowledge-able.com 